\title{
The nest, egg, and nestling of Many-striped Canastero Asthenes flammulata flammulata (Furnariidae) in northeastern Ecuador
}

\author{
Harold F. Greeney \\ Yanayacu Biological Station \& Center for Creative Studies, km 5, vía Las Caucheras, Cosanga, Napo, Ecuador.E-mail: antpittanest@gmail.com
}

Editado por/Edited by: Esteban A. Guevara

Recibido/Received: 23 Noviembre 2018 Aceptado/Accepted: 4 Octubre 2019

Publicado en línea/Published online: 22 Marzo 2020

\section{Nido, huevo y pichón del Canastero Multilistado Asthenes flammulata flammulata (Furnariidae) en el noreste de Ecuador}

\begin{abstract}
Resumen
El género Asthenes incluye alrededor de 27-30 especies de furnáridos predominantemente distribuidos en áreas montanas . Durante trabajo de campo en los altos Andes del noreste de Ecuador, descubrí cuatro nidos del Canastero Multilistado Asthenes flammulata flammulata. Todos los nidos eran estructuras musgosas, casi esféricas, con una entrada lateral y toda la cámara interior forrada con una gruesa capa de envolturas de semillas y pelaje. Todos los nidos fueron construidos en cavidades naturales formadas por vegetación densamente enredada, en o muy cerca del suelo. Dos puestas consistían en dos huevos cada una. Los huevos eran de color blanco inmaculado, de forma corta, ovalada. Los polluelos tenían piel de color naranja-rosado, con plumón de color gris en todas las áreas dorsales. Los picos de los polluelos eran de color naranjaopaco, con comisuras amarillo brillante y el interior de la boca era amarillo-anaranjado brillante. En forma general, los nidos y huevos descritos aquí son similares a otros miembros del género. Sin embargo, una revisión exhaustiva de la literatura indicó que más de la mitad de las especies de Asthenes actualmente reconocidas aún carecen de descripciones de sus nidos. Entre ellas se encuentran tres especies de interés para la conservación a nivel mundial.
\end{abstract}

Palabras clave: Andes, Asthenes flammulata, biología reproductiva, Canastero Multilistado, Furnariidae, historia natural, nido, pichón.

\begin{abstract}
The genus Asthenes includes around 27-30 species of slender, long-tailed furnariids, predominantly montane in distribution. During fieldwork in the high Andes of northeastern Ecuador, I discovered four nests of Many-striped Canastero A. flammulata flammulata. All nests were mossy, nearly spherical balls, with a centrally placed side entrance, and with the entire inner chamber lined with a thick layer of seed down and fur. All were built into natural cavities formed by densely tangled vegetation, on or very near the ground. Two clutches consisted of two eggs each. Eggs were immaculate white, oval to short-oval in shape. Nestlings had orange to pinkish skin at hatch, with sparse gray down plumes on all dorsal feather tracts. Their bills were dull orange with bright yellow rictal flanges, and their mouth linings were bright orangeyellow. In general form, the nests and eggs described here are similar to other members of the genus. A thorough review of the literature, however, indicates than half of the currently-recognized Asthenes species have yet to have their nests described. Among these, three species of global conservation concern.
\end{abstract}

Keywords: Andes, Asthenes flammulata, breeding biology, life history, Many-striped Canastero, natural history, paramo, reproduction.

Members of the genus Asthenes, as currently defined, have been historically placed in numerous other genera including Siptornis, Schizoeca, Thripophaga, and Synallaxis (Cory \& Hellmayr, 1925; Peters, 1951). Recently, several additional genera have been merged with Asthenes (e.g., Schizoeca, Oreophylax), and several species have been placed in the newly-erected genus Pseudoasthenes (Irestedt et al., 2006, 2009; Moyle et al., 2009; Derryberry et al., 2010, 2011; Remsen et al., 2018). Thus, there are currently 27-30 species in the genus 
(Dickinson \& Christidis, 2014; del Hoyo \& Collar, 2016; Remsen et al., 2018). Many-striped Canastero Asthenes flammulata lives at elevations above $2800 \mathrm{~m}$ a.s.l., in the high Andes from northern Colombia to southern Peru (Remsen, 2003; Ridgely \& Tudor, 2009). In Ecuador, it occurs at 3200-4500 m a.s.1., and is fairly common where it occurs (Ridgely \& Greenfield, 2001; Freile \& Restall, 2018). Despite this, its nesting biology remains completely unstudied, apart from a single report of an active nest in Ancash, Peru (Fjeldså \& Krabbe, 1990). Here I provide a description of the nest, eggs, and nestlings of this species based on four nests found in northeast Ecuador, and include a thorough review of the literature on Asthenes nesting biology.

I studied four nests in the vicinity of the pass above Papallacta, Napo, Ecuador $(-0.332756,-78.200326)$. Habitat in this area is mostly humid paramo interspersed with patches of elfin forest covering those areas most sheltered from the wind. For more detailed habitat descriptions see Greeney \& Harms (2008) and Greeney et al. (2011). I found nests opportunistically, during the course of other fieldwork, and was not able to revisit them with any regularity. The first nest was located at $4200 \mathrm{~m}$ a.s.l. On 13 December 2004 it contained two nestlings, approximately one day after their primary pin feathers ruptured their sheaths. On 29 September 2005, at 4000 $\mathrm{m}$ a.s.l., a second nest contained two eggs, one that was addled and one that hatched on 1 October. At this same elevation, a third nest contained two nestlings on 1 November 2006. The primaries of both nestlings appeared to have broken their sheaths $c$. 1-2 days previously. The fourth nest contained two eggs on 18 October 2006 at $3950 \mathrm{~m}$ a.s.l. One of these eggs was also addled, but the second egg was pipped when I examined them on 25 October. My only other observation on breeding activity in this area was a pair of adults feeding a stub-tailed juvenile on 26 November 2011, at $3950 \mathrm{~m}$ a.s.l. in the same area.

All four nests (Figs. 1, 2a, 2b) were thick, mossy balls, nearly spherical and with a centrally placed side entrance. All were built into natural, above-ground cavities formed by densely tangled bunch grass (Festuca sp.). The height of nests above the ground was difficult to assess, but was never more than $20 \mathrm{~cm}$. Most nests would likely have been categorized as being on the ground by the casual observer. Mean dimensions of three nests $(\mathrm{cm} \pm$ SD) were: outer diameter perpendicular to entrance, $15.8 \pm 1.0$; outer diameter front-to-back, $15.3 \pm 1.5$; outer height, $15.7 \pm 1.2$; entrance width, $4.8 \pm 0.2$; entrance height, $4.4 \pm 7.7$; internal chamber width, $7.3 \pm 0.3$; internal height from bottom of egg-cup, $7.5 \pm 0.5$, egg-cup diameter, $5.8 \pm 0.8$; and egg-cup depth, $4.3 \pm 0.8$.

Nests were all similar in composition. Their external portions were composed of a mixture of moss, small sticks, and grass stems, with the relative proportion of moss much reduced closer to the center. Within this outer shell, the entire nesting chamber was lined with a 1-1.5 cm thick layer of Puya sp. seed down (Bromeliaceae) and mammal fur, thickest in the lower portions of the nest. The egg-cup was further insulated with an additional 0.5-1 $\mathrm{m}$ of these same materials, with the inner portion of the cup also including a few feathers and, in some cases, a few short, flexible pieces of grass stems. The feathers appeared to be those of other species, but it seems possible that the grass stems in some nests fell in accidentally or perhaps came loose from the inner wall of the nest chamber.

The four eggs I examined were immaculate white (Fig. 2c), oval to short-oval in shape (following Harrison, 1984). Mean measurements $(\mathrm{mm})$ were: $23.5 \pm 0.8 \times 17.8 \pm 0.4$. Nestlings were orange to pinkish-skinned at hatch (Fig. 2d), with sparse gray down plumes on all dorsal feather tracts. Their bills were dull orange with bright yellow rictal flanges, and their mouth linings were bright orange-yellow. The two half-grown nestlings (just prior to the emergence of primary pin feathers from their sheaths) weighed 19.4 and $17.3 \mathrm{~g}$. Another two nestlings, 1-2 days after primaries broke their sheaths weighed 23.5 and $22.8 \mathrm{~g}$.

As expected, the eggs of A.f. flammulata are immaculate white, as those of its congeners (Nehrkorn, 1899, 1910, 1914; Oates \& Reid, 1903; Hartert \& Venturi, 1909; Smyth, 1928; Hellmayr, 1932; Kreuger, 1967; Schönwetter, 1979; Remsen, 2003). A clutch of two eggs is also similar to the more equatorial Asthenes species. Previous nest descriptions within Asthenes sensu lato (Derryberry et al., 2010, 2011; Dickinson \& Christidis, 2014) are available for 20 taxa (Table 1). Nests of Hudson's Canastero A. hudsoni, Streak-throated Canastero A. h. humilis, and Cipo Canastero A. luizae all appear particularly similar to the nests of A.f. flammulata described here. Even with the description of the nest of A.f.flammulata, the nest architecture and placement of more than half of the recognized species of Asthenes remain unavailable for comparison. Furthermore, breeding biology of the 14 species lacking nest descriptions, including three species of conservation concern (BirdLife International, 2019), remains almost entirely unknown: Berlepsch's Canastero A. berlepschi (Near Threatened); Line-fronted Canastero A. urubambensis, Junín Canastero A. virgata, Scribble-tailed Canastero A. maculicauda, 
Puna Thistletail A. helleri (Vulnerable), Ayacucho Thistletail A. ayacuchensis, Vilcabamba Thistletail A. vilcabambae, Canyon Canastero A. pudibunda, Rusty-fronted Canastero A. ottonis, Maquis Canastero A. heterura, Eye-ringed Thistletail A. palpebralis, Ochre-browed Thistletail A. coryi, Perija Thistletail A. perijana (Endangered), and Mouse-colored Thistletail (A.griseomurina).
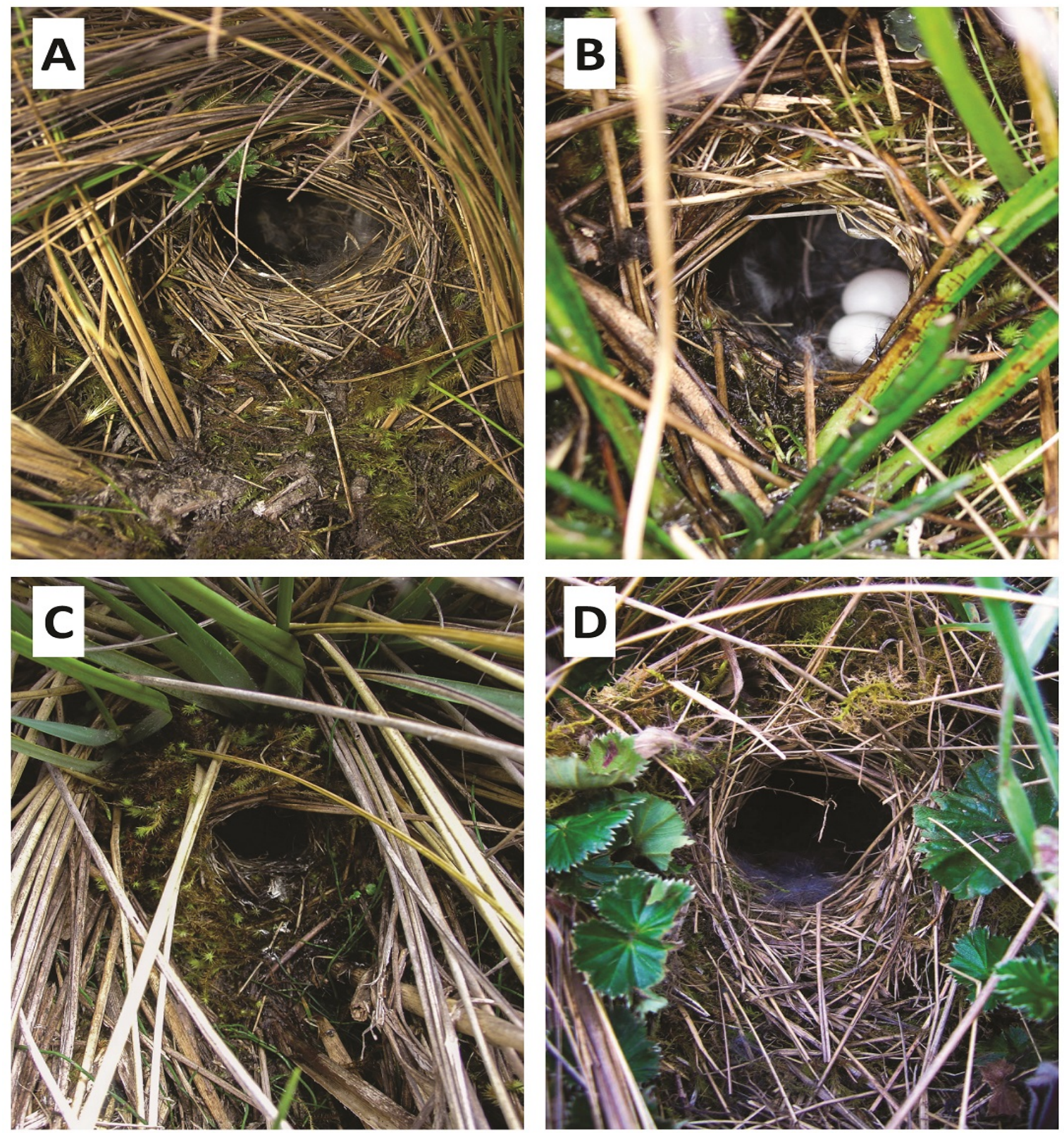

Figure 1: Nests of Many-striped Canastero Asthenes f. flammulata near Papallacta, Napo, Ecuador (H. F. Greeney).

Despite the ever-growing body of literature available on the biology of Neotropical birds (Freile et al., 2014), our knowledge of their reproductive ecology, particularly in megadiverse countries such as Ecuador (Greeney, 2015), remains far from complete (Heming et al., 2013). On the bright side, both historical and current nesting records can now be searched and acquired with increasing ease via online resources like Scopus (https://www.scopus.com/home.uri) and Biodiversity Heritage Library (https://www.biodiversitylibrary.org/). Nevertheless, the volume of available ornithological literature is vast and is expanding exponentially, making the compilation and organization of information a daunting and time-consuming task. As scientists and academic authors, we all stand upon the shoulders of those who came before us, just as future generations should rely on our own published works. Work we carry out now will be, and should be, a benefit to future authors. I therefore encourage not only the publication of breeding information on Neotropical birds, but also the inclusion of a well-researched bibliography relating to the taxa and topics covered in each publication. 

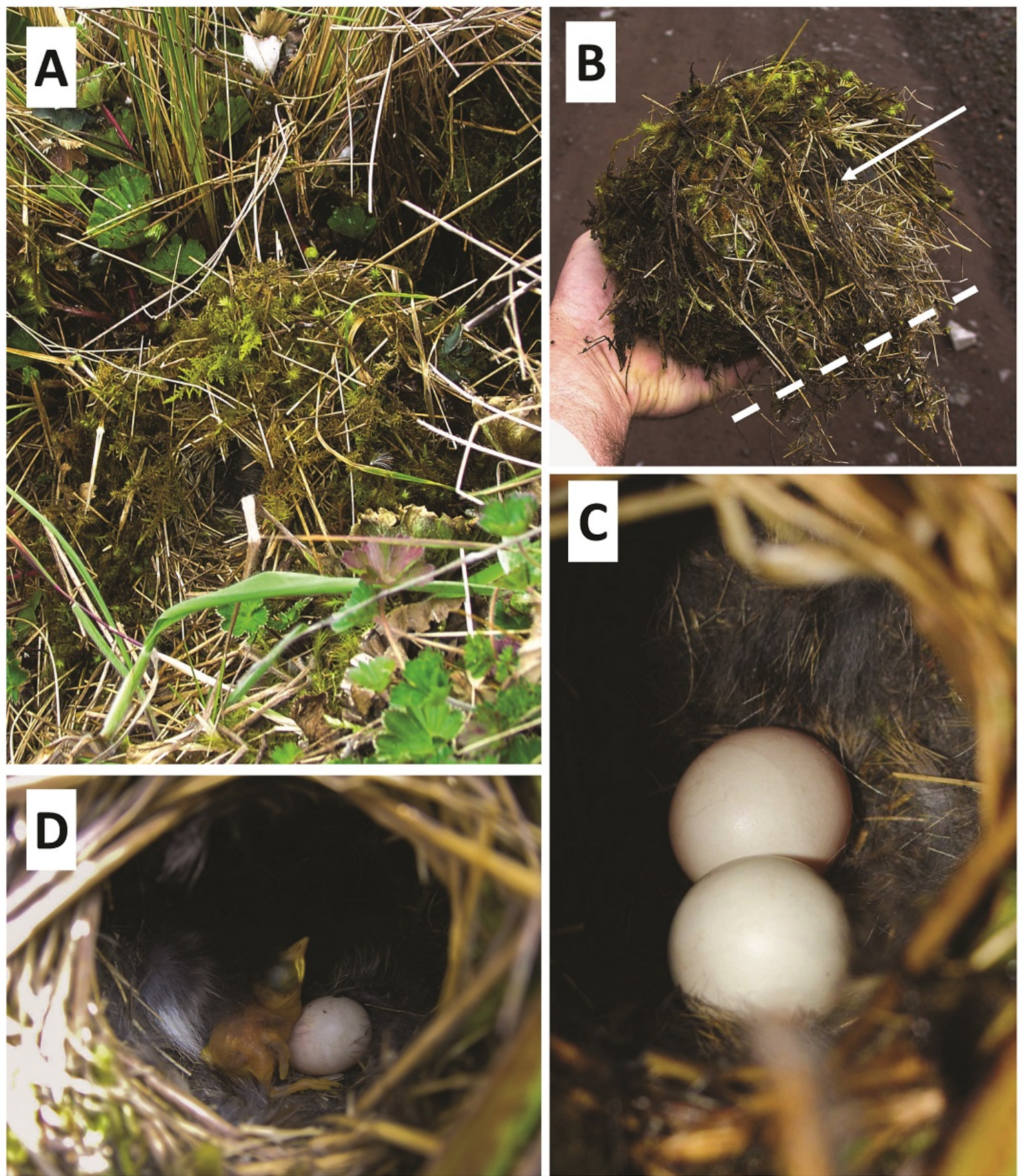

Figure 2: Breeding biology of Many-striped Canastero Asthenes f. flammulata near Papallacta, Napo, Ecuador. A) Nest, in situ, with surrounding vegetation removed; B) lateral view of a nest (held at an upward-tilted angle), ex situ. The white arrow indicates location of entrance and dashed white line shows the orientation of the ground below the nest; C) complete clutch of two immaculate white eggs. Note the thick layer of mammalian fur within the nest chamber; D) egg and newlyhatched nestling inside nest.

\section{ACKNOWLEDGEMENTS}

I thank José Simbaña and the staff of Yanayacu Biological Station \& Center for Creative Studies for logistical support, and Kristof Zyskowski, Eliot T. Miller, Rudy A. Gelis, and Inka Harms for help in the field. John V. and the late Ruth Ann Moore, Matt Kaplan, and Field Guides Inc. provided support through the Population Biology Foundation, with the aid of Thomas R. Walla. The writing of this manuscript was facilitated by a fellowship from the John Simon Guggenheim Memorial Foundation. 
Table 1: Published nest descriptions for the genus Asthenes (Furnariidae).

\begin{tabular}{|c|c|c|}
\hline English name & Latin name & Source \\
\hline Creamy-breasted Canastero & A. dorbignyi dorbignyi & $\begin{array}{l}\text { Lönnberg, 1903; Narosky et al., 1983; } \\
\text { Salvador, } 2015 .\end{array}$ \\
\hline Dark-winged (Arequipa) Canastero & A. dorbignyi arequipae & $\begin{array}{l}\text { Dorst 1956, 1957; Fjeldså \& Krabbe, } \\
\text { 1990; Lüthi } 2011 .\end{array}$ \\
\hline $\begin{array}{l}\text { Pale-tailed (Huancavelica) } \\
\text { Canastero }\end{array}$ & A. dorbignyi huancavelicae & Morrison, 1939. \\
\hline White-tailed Canastero & A. dorbignyi usheri & Fjeldså \& Krabbe, 1990. \\
\hline Short-billed Canastero & A. baeri baeri & $\begin{array}{l}\text { Hartert \& Venturi, 1909; Pereyra, } \\
\text { 1937; de la Peña, 1987; Mezquida, } \\
\text { 2000, } 2001 .\end{array}$ \\
\hline Cipo Canastero & A. luizae & $\begin{array}{l}\text { Studer \& Teixiera, 1993; Gomes \& } \\
\text { Rodriguez, } 2010 .\end{array}$ \\
\hline Hudson's Canastero & A. hudsoni & $\begin{array}{l}\text { Dalgleish, 1881; Sclater \& Hudson, } \\
\text { 1888; Hartert \& Venturi, 1909; Grant, } \\
\text { 1911; Hudson, 1920; Wetmore, 1926; } \\
\text { Wilson, } 1926 .\end{array}$ \\
\hline Austral Canastero & A. anthoides & $\begin{array}{l}\text { Pässler, 1922; Hellmayr, 1932; } \\
\text { Philippi et al., 1954; Narosky et al., } \\
\text { 1983. }\end{array}$ \\
\hline Many-striped Canastero & A.f.flammulata & This study. \\
\hline \multirow{2}{*}{ Streak-backed Canastero } & A. wyatti graminicola & Dorst, 1963. \\
\hline & A. w. aequatorialis & Phelps, 1977. \\
\hline Puna Canastero & $\begin{array}{l}\text { A. s. sclateri } \\
\text { A. sclateri punensis }\end{array}$ & $\begin{array}{l}\text { Narosky et al., 1983; de la Peña, } 1987 . \\
\text { Höy, } 1975 .\end{array}$ \\
\hline Streak-throated Canastero & A.h.humilis & Vaurie, 1980. \\
\hline Cordilleran Canastero & A. m. modesta & $\begin{array}{l}\text { Goodall et al., 1957; Johnson \& } \\
\text { Goodall, 1967; de la Peña, } 1987 .\end{array}$ \\
\hline & A. m. australis & $\begin{array}{l}\text { Goodall et al., 1957; Johnson \& } \\
\text { Goodall, 1967; Narosky et al., } 1983 .\end{array}$ \\
\hline Itatiaia Spinetail & A. moreirae & Sick, 1970, 1993. \\
\hline Sharp-billed Canastero & A.p.pyrrholeuca & $\begin{array}{l}\text { Wetmore, 1926; Pereyra, 1937; Nores } \\
\text { \& Yzurieta, 1975; Narosky et al., } \\
1983 .\end{array}$ \\
\hline Sharp-billed Canastero & A.p. sordida & $\begin{array}{l}\text { Goodall et al., 1957; Johnson \& } \\
\text { Goodall, } 1967 .\end{array}$ \\
\hline Black-throated Thistletail & A. harterti bejaranoi & Vuilleumier, 1969. \\
\hline White-chinned Thistletail & A.f.fuliginosa & Hilty \& Brown, 1986. \\
\hline
\end{tabular}

\section{REFERENCES}

BirdLife International (2019, 30 September). IUCN Red List for birds. Cambridge, UK: BirdLife International. URL: http://www.birdlife.org

Cory, C. B., \& Hellmayr, C. E. (1925). Catalogue of birds of the Americas. Part IV. Furnariidae, Dendrocolaptidae. Zoological Series, Field Museum of Natural History, 13(234), 1-390. URL: https://www.biodiversitylibrary.org/item/20942

Dalgleish, J.J. (1881). Notes on a collection of birds and eggs from central Uruguay. Proceedings of the Royal Physical Society of Edinburgh, 10, 232-254. 
Derryberry, E. P., Claramunt, S., Derryberry, G., Chesser, R. T., Cracraft, J., Aleixo, A., Pérez-Emán, J., Remsen, J. V., Jr., \& Brumfield, R. T. (2011). Lineage diversification and morphological evolution in a largescale continental radiation: The neotropical ovenbirds and woodcreepers (Aves: Furnariidae). Evolution, 65(10), 2973-2986. DOI: https://doi.org/10.1111/j.1558-5646.2011.01374.x

Derryberry, E. P., Claramunt, S., O'quin, K. E., Aleixo, A., Chesser, R. T., Remsen, J. V., Jr., \& Brumfield, R. T. (2010). Pseudoasthenes, a new genus of ovenbird (Aves: Passeriformes: Furnariidae). Zootaxa, 2416, 6168. URL: http://www.mapress.com/zootaxa/list/2010/2416.html

Dickinson, E. C., \& Christidis, L. (2014). The Howard and Moore complete checklist of the birds of the world. 4th Edition. Volume 2, Passerines. Eastbourne, U.K.: Aves Press.

Dorst, J. (1956). Recherches ecologiques sur les oiseaux des hauts plateaux peruviens. Travaux de L'Institut Francais d'Etudes Andines, 5, 83-140.

Dorst, J. (1957). The puya stands of the Peruvian high plateaux as a bird habitat. Ibis 99(4), 594-599. DOI: https://doi.org/10.1111/j.1474-919X.1957.tb03051.X

Dorst, J. (1963). Note sur la nidification et le comportement acoustique du jenue Asthenes wyatti punensis au Pérou. L'Oiseau et la Revue Francaise d'Ornithologie, 33, 1-6.

Fjeldså, J., \& Krabbe, N. (1990). The birds of the high Andes. Svendborg \& Copenhagen, Denmark: University of Copenhagen \& Apollo Books.

Freile, J. F., \& Restall, R. (2018). Birds of Ecuador. London, U.K.: Helm Field Guides.

Freile, J. F., Greeney, H. F. \& Bonaccorso, E. (2014). Current Neotropical ornithology: research progress 19962007. Condor: Ornithological Applications, 116(1), 84-96. DOI: https://doi.org/10.1650/CONDOR-12-152$\underline{\mathrm{R} 1.1}$

Gomes, H. B., \& Rodrigues, M. (2010). The nest of Cipó Canastero (Asthenes luizae), an endemic furnariid from the Espinhaço Range, southeastern Brazil. Wilson Journal of Ornithology, 122(3), 600-603. DOI: https://doi.org/10.1676/08-098.1

Goodall, J. D., Johnson, A. W., \& Philippi, R. A. (1957). Las aves de Chile, sus conocimientos y sus costumbres. Buenos Aires, Argentina: Platt Establecimientos Gráficos, S.A.

Grant, C.H.B. (1911). List of birds collected in Argentina, Paraguay, Bolivia and southern Brazil, with fieldnotes. Part I. Passeres. Ibis, 53(1), 80-137. DOI: https://doi.org/10.1111/j.1474-919X.1911.tb03303.X

Greeney, H. F. (2015). Anidación de la avifauna ecuatoriana: dónde estamos y hacia dónde vamos. In D. F. Cisneros-Heredia, J. F. Freile \& E. Guevara (Eds.), Resúmenes de la IV Reunión Ecuatoriana de Ornitología (p. 9). Quito, Ecuador: Archivos Académicos USFQ, Número 3.

Greeney, H. F., \& Harms, I. (2008). Behavior of the Tawny Antpitta (Grallaria quitensis) in northern Ecuador. Ornitología Neotropical, 19(1), 143-147.

URL: https://sora.unm.edu/sites/default/files/ON\%20\%2819\%29\%20143-148.pdf

Greeney, H. F., Martin, P. R., Gelis, R. A., Solano-Ugalde, A., Bonier, F., Freeman, B. G., \& Miller, E. T. (2011). Notes on the breeding of high-Andean birds in northern Ecuador. Bulletin of the British Ornithologists Club, 131(1), 24-31. URL: https://www.biodiversitylibrary.org/item/206985

Harrison, C. J. O. (1984). A field guide to the nests, eggs, and nestlings of North American birds. Brattleboro, Vermont: Stephen Greene Press. 
Hartert, E., \& Venturi, S. (1909). Notes sur les oiseaux de la Republique Argentine. Novitates Zoologicae, 16(2), 159-267. DOI: https://doi.org/10.5962/bhl.part.21963

Hellmayr, C. E. (1932). The birds of Chile. Field Museum of Natural History (Zoological Series), 20(308), 1472. URL: https://www.biodiversitylibrary.org/item/20866

Heming, N. M., Greeney, H. F., \& Marini, M. Â. (2013). Breeding biology research and information availability for New World birds. Natureza \& Conservação, 11(1), 54-58.

Hilty, S. L., \& Brown, W. L. (1986). A guide to the birds of Colombia. Princeton, NJ: Princeton University Press.

Höy, G. (1975). Le nid et les oeufs de Tripophaga punensis (Berlepsch et Stolzmann) (Furnariidae). L'Oiseau et la Revue Francaise d'Ornithologie, 45, 189-191.

del Hoyo, J., \& Collar, N. J. (2016). HBW and BirdLife International illustrated checklist of birds of the world, vol. 2: Passerines. Barcelona, Spain: Lynx Edicions.

Hudson, W. H. (1920). Birds of La Plata. Volume 1. London, U.K.: E. P. Dutton \& Co. DOI: https://doi.org/10.5962/bhl.title.22233

Irestedt, M., Fjeldså, J., Dalén, L., \& Ericsson, P. G. P. (2009). Convergent evolution, habitat shifts and variable diversification rates in the ovenbird-woodcreeper family (Furnariidae). BMC Evolutionary Biology, 9, art. 268. DOI: https://doi.org/10.1186/1471-2148-9-268

Irestedt, M., Fjeldså, J. \& Ericsson, P. G. P. (2006). Evolution of the ovenbird-woodcreeper assemblage (Aves: Furnariidae) - major shifts in nest architecture and adaptive radiation. Journal of Avian Biology, 37(3), 260 272. DOI: https://doi.org/10.1111/j.2006.0908-8857.03612.x

Johnson, A. W., \& Goodall, J. D. (1967). The birds of Chile and adjacent regions of Argentina, Bolivia, and Peru. Buenos Aires, Argentina: Platt Establecimientos Gráficos, S.A.

Kreuger, R. (1967). Notes on the oology of members of the Eurylaimidae (broadbills), Dendrocolaptidae (woodhewers) and Furnariidae (ovenbirds) in the Museum R. Kreuger, Helsinki. Oölogists' Record, 41(3), 43-48.

Lönnberg, E. (1903). On a collection of birds from north-western Argentina and the Bolivian Chaco. Ibis, 45(4), 441-471. DOI: https://doi.org/10.1111/j.1474-919X.1903.tb03953.X

Lüthi, H. (2011). Birdwatching in Peru: 1963-2006. Revista Peruana de Biologia, 18(1), 27-90. DOI: http://dx.doi.org/10.15381/rpb.v18i1.170

Mezquida, E. T. (2000). Ecologia reproductiva de un ensamble de aves del desierto del Monte Central, Argentina. Madrid, Spain: Universidad Autónoma de Madrid (PhD Dissertation).

Mezquida, E. T. (2001). La reproducción de algunas especies de Dendrocolaptidae y Furnariidae en el Desierto del Monte central, Argentina. Hornero, 16, 37-44.

URL: http://digital.bl.fcen.uba.ar/Download/008 ElHornero/008 ElHornero v016 n01 articulo023.pdf

Morrison, A. (1939). The birds of the Department of Huancavelica, Peru. Ibis, 81(3), 453-486. DOI: https://doi.org/10.1111/j.1474-919X.1939.tb07883.X

Moyle, R. G., Chesser, R. T., Brumfield, R. T., Tello, J. G., Marchese, D. J., \& Cracraft, J. (2009). Phylogeny and phylogenetic classification of the antbirds, ovenbirds, woodcreepers, and allies (Aves: Passeriformes: infraorder Furnariides). Cladistics, 25, 386-405. DOI: https://doi.org/10.1111/j.1096-0031.2009.00259.x 
Narosky, S., Fraga, R., \& de La Peña, M. (1983). Nidificación de las aves argentinas (Dendrocolaptidae y Furnariidae). Buenos Aires, Argentina: Asociación Ornitológica de la Plata.

Nehrkorn, A. (1899). Katalog der Eiersammlung nebst Beschreibungen der Aussereuropäschen Eier. Braunschweig, Germany: Harald Bruhn. URL: http://www.biodiversitylibrary.org/bibliography/13722

Nehrkorn, A. (1910). Katalog der Eiersammlung nebst Beschreibungen der aussereuropäschen Eier. 2 Auflage. Berlin, Germany: R. Frieländer \& Sohn. URL: http://www.biodiversitylibrary.org/bibliography/7497

Nehrkorn, A. (1914). Nachträge zu Nehrkorn's Eierkatalog Berlin, Germany: R. Friedländer \& Sohn. https://doi.org/10.5962/bhl.title.12514

Nores, M., \& Yzurieta, D. (1975). Sobre aves de la provincia de Córdoba. Hornero, 11(4), 312-314. URL: http://digital.bl.fcen.uba.ar/Download/008 ElHornero/008 ElHornero v011 n04 articulo312.pdf

Oates, E. W., \& Reid, S. G. (1903). Catalogue of the collection of birds' eggs in the British Museum (Natural History). Volume 3: Carinatae (Psittaciformes-Passeriformes). London, U.K.: British Museum of Natural History.

Pässler, R. (1922). In der Umgebung Coronel's (Chile) beobachtete Vögel. Beschreibung der Nester und Eier der Brutvögel. Journal für Ornithologie, 70(4), 430-482. DOI: https://doi.org/10.1007/BF02538208

de La Peña, M. R. (1987). Nidos y huevos de aves Argentinas. Santa Fe, Argentina: Published by the Author.

Pereyra, J. A. (1937). Contribución al estudio y observaciones ornitológicas de la zona norte de la Gobernación de La Pampa. Memorias del Jardín Zoologico de La Plata, 7, 198-321.

Peters, J. L. (1951). Check-list of birds of the world, vol. 7. Cambridge, Massachusetts: Museum of Comparative Zoology, Harvard. URL: https://www.biodiversitylibrary.org/item/50584

Phelps, W. H., Jr. (1977). Una nueva especie y dos nuevas subespecies de aves (Psittacidae, Furnariidae) de la Sierra de Perija cerca de la divisoria colombo-venezolana. Boletin de la Sociedad Venezolana de Ciencias Naturales, 33, 43-53.

Philippi B., R. A., Johnson, A. W., Goodall, J. D., \& Behn, F. (1954). Notas sobre aves de Magallanes y Tierra del Fuego. Boletin del Museo Nacional de Historia Natural, Santiago, Chile, 26, 1-63. URL: http://publicaciones.mnhn.cl/668/articles-63954 archivo 01.pdf

Remsen, J. V., Jr. (2003). Family Furnariidae (Ovenbirds). In J. Del Hoyo, A. Elliott, \& J. Sargatal. (Eds), Handbook of the birds of the world, Volume 8: broadbills to tapaculos (pp. 162-357). Barcelona, Spain: Lynx Edicions.

Remsen, J. V., Jr., Areta, J. I., Cadena, C. D., Claramunt, A., Jaramillo, A., Pacheco, J. F., Pérez-Emán, J., Robbins, M. B., Stiles, F. G., Stotz, D. F., \& Zimmer, K. J. (2018, 30 March). A classification of the bird species of South America. American Ornithologists Union.

URL: http://www.museum.lsu.edu/ Remsen/SACCBaseline.html

Ridgely, R. S., \& Greenfield, P. J. (2001). Birds of Ecuador. Ithaca, New York: Cornell University Press.

Ridgely, R. S., \& Tudor, G. (2009). Field guide to the songbirds of South America: the Passerines. Austin, Texas: University of Texas Press.

Salvador, S. A. (2015). Reproducción de aves andinas del Noroeste argentino. Historia Natural (tercera serie), 5(1), 49-76. URL: https://www.researchgate.net/publication/294874868 
Schönwetter, M. (1979). Handbuch der Oölogie (vol. 2). Berlin, Germany: Akademie-Verlag.

Sclater, P. L., \& Hudson, W. H. (1888). Argentine ornithology: a descriptive catalogue of the birds of the Argentine Republic. London, U.K.: Taylor \& Francis. DOI: https://doi.org/10.5962/bhl.title.20448

Sick, H. (1970). Der Strohschwanz, Oreophylax moreirae, andiner Furnariide in Sudostbrasilien. Bonner Zoologische Beitrage, 21, 251-268. URL: https://www.biodiversitylibrary.org/item/156068

Sick, H. (1993). Birds in Brazil: a natural history. Princeton, New Jersey: Princeton University Press.

Smyth, C. H. (1928). Descripción de una colección de huevos de aves argentinas. Hornero, 4, 125-152.

Studer, A., \& Teixeira, D. M. (1993). Notas sobre a biologia reprodutiva de Asthenes luizae Vielliard, 1990 (Aves, Furnariidae). Pelotas, Brazil: III Congresso Brasileiro de Ornitologia.

Vaurie, C. (1980). Taxonomy and geographical distribution of the Furnariidae (Aves, Passeriformes). Bulletin of the American Museum of Natural History, 166, 1-357.

Vuilleumier, F. (1969) Field notes on some birds from the Bolivian Andes. Ibis, 111, 599-608.

Wetmore, A. (1926) Observations on the birds of Argentina, Paraguay, Uruguay, and Chile. Bulletin of the United States National Museum, 133, 1-448. DOI: https://doi.org/10.5479/si.03629236.133.i

Wilson, A. S. (1926). Lista de aves del sur de Santa Fe. Hornero, 3(4), 349-363. 